\title{
Variasi Penggunaan Jenis Bahan Baku (Air Cucian Beras dan Air Kelapa) dengan Penambahan Ekstrak Tauge terhadap Rendemen dan Mutu Nata
}

\author{
(Variation of Raw Material (Rice and Coconut Water) with the Addition of Bean Sprouts \\ Extracts to the Yield and Quality of Nata)
}

\author{
Nurul Izzati ${ }^{1}, \operatorname{Irfan}^{1}$, Syarifah Rohaya ${ }^{1^{*}}$ \\ ${ }^{1}$ Program Studi Teknologi Hasil Pertanian, Fakultas Pertanian, Universitas Syiah Kuala
}

\begin{abstract}
Abstrak. Penelitian ini bertujuan untuk mengkaji proses variasi penggunaan jenis bahan baku air cucian beras dan air kelapa dengan penambahan konsentrasi ekstrak tauge terhadap rendemen dan mutu nata yang dihasilkan. Penelitian ini menggunakan Rancangan Acak Lengkap (RAL) pola faktorial dengan faktor jenis bahan baku (B) dan onsentrasi ekstrak tauge (K). Jenis bahan baku (B) terdiri dari 2 taraf yaitu $\mathrm{B} 1=$ air cucian beras dan $\mathrm{B} 2=$ air kelapa, sedangkan kosentrasi ekstrak tauge terdiri dari 5 taraf yaitu $\mathrm{K} 1=0 \%, \mathrm{~K} 2=0.25 \%, \mathrm{~K} 3=0.5 \%, \mathrm{~K} 4=0.75 \%$ dan $\mathrm{K} 5=15 \%$. Ulangan dilakukan 2 kali dan diperoleh 20 satuan percobaan. Analisis yang dilakukan yaitu rendemen, kadar air, serat kasar, ketebalan dan tekstur. Hasil penelitian menunjukkan bahwa penggunaan jenis bahan baku dan konsentrasi ekstrak tauge berpengaruh sangat nyata terhadap rendemen dan kadar air. Adapun penggunaan jenis bahan baku berpengaruh sangat nyata terhadap kadar air nata sedangkan pada penambahan konsentrasi ekstrak tauge berpengaruh nyata. Nata de rice dan nata de coco memiliki rendemen berkisar dari $2.01 \%-8.23 \%$, kadar air $69.11 \%-81.49 \%$, serat kasar $4.57 \%-9.38 \%$, ketebalan $0.02 \mathrm{~cm}-0.57 \mathrm{~cm}$ dan tekstur $67 \mathrm{~g} / \mathrm{cm}^{2}-289.5 \mathrm{~g} / \mathrm{cm}^{2}$.
\end{abstract}

Kata kunci: Air cucian beras, air kelapa, tauge, gula, Acetobacter xylinum.

\begin{abstract}
This study aims to examine the process of variation in the use of types of raw materials for rice washing and coconut water by adding bean sprouts extract to the yield of nata quality produced. This study used a completely randomized design (CRD) factorial pattern whith raw material type factors (B) and bean sprout extract $(\mathrm{K})$. Raw material (B) consists of 2 levels, namely $\mathrm{B} 1=$ rice washing water and $\mathrm{B} 2=$ coconut water, while bean sprout extract consists of 5 levels, namely $\mathrm{K} 1=0 \%, \mathrm{~K} 2=0.25 \%, \mathrm{~K} 3=0.5 \%, \mathrm{~K} 4=0,75 \%$ dan $\mathrm{K} 5=1 \%$. Deuteronomy was done twice and 20 experimental units were obtained. The analysis carried out was the yield, moisture content, crude fiber, texture, thickness. The results showed that the use of raw materials and exstraction of bean sprouts significantly affected the yield and moisture content. The use of raw material for rice washing water and coconut water has a very significant effect on water content and has a significant effect on bean extract. Nata de rice and nata de coco have yields ranging from $2.01 \%-8.23 \%$, moisture content $69.11 \%$ $81.49 \%$, crude fiber $4.57 \%-9.38 \%$, thickness $0.02 \mathrm{~cm}-0.57 \mathrm{~cm}$ and texture $67 \mathrm{~g} / \mathrm{cm}^{2}-289.5 \mathrm{~g} / \mathrm{cm}^{2}$.
\end{abstract}

Keywords: Rice washing water, coconut water, bean sprouts, sugar, Acetobacter xylinum.

\section{PENDAHULUAN}

Nata merupakan suatu produk makanan yang berupa lapisan selulosa yang terbentuk dari hasil fermentasi bakteri pembentuk nata yaitu Acetobacter xylinum (Dewi, 2009). Bahan baku yang sering digunakan dalam pembuatan nata adalah air kelapa. Seiring dengan berkembangnya teknologi bahan pembuatan nata semakin beragam dapat dibuat dari sari jagung, sari buah mangga, sari buah nanas, lidah buaya, dan limbah cair tahu.

Air kelapa (Cocos nucifera) merupakan salah satu bagian dari buah kelapa yang kurang dimanfaatkan dan biasanya hanya menjadi limbah yang terbuang begitu saja di lingkungan. Air kelapa sangat bagus digunakan dalam pembuatan nata de coco, karena di dalam air kelapa masih mengandung nutrisi yang dibutuhkan bagi pertumbuhan, perkembangbiakan dan aktivitas bibit nata Acetobacter xylinum (Pambayun, 2002). Kandungan utama yang terdapat pada air kelapa adalah karbohidrat, glukosa, fruktosa dan sukrosa (Gustian et al., 2006). 
Menurut Pambayun (2002), nata tidak hanya dibuat dari air kelapa saja tetapi juga bisa dibuat dari berbagai jenis bahan yang mengandung gula, protein, mineral, misalnya nata de pina, nata de mango, dan nata de soya. Air cucian beras merupakan salah satu limbah rumah tangga yang dapat dimanfaatkan sebagai bahan baku pembuatan nata. Dewasa ini air cucian beras hanya menjadi limbah dan kurang pemanfaatannya, padahal air cucian beras masih mengandung nutrisi dan vitamin yang tinggi seperti sakarida jenis pati sebanyak $85-90 \%$, glutein, selulosa, vitamin B1 yang ikut terlarut saat proses pencucian beras. Kandungan sakarida yang terdapat pada air cucian beras dapat dimanfaatkan untuk pertumbuhan bakteri Acetobacrter xylinum dalam pembuatan nata (Fitrah, 2007). Nata sangat bermanfaat untuk kesehatan karena dapat mencegah para penderita diabetes, memperlancar dalam proses pencernaan dan bagus untuk diet (Sihmawati et al., 2014).

Proses pembuatan nata merupakan suatu upaya dalam memanfaatkan limbah cair menjadi suatu produk bahan makanan yang mempunyai nilai tambah. Keberhasilan dalam pembuatan nata dapat dipengaruhi oleh banyak faktor. Nutrisi pendukung yang sangat penting dalam pembuatan nata yaitu gula dan ammonium sulfat (Patria et al., 2013). Untuk memperoleh hasil nata yang optimum diperlukan nutrisi secara eksponen berupa sumber karbon dan nitrogen (Lapuz et al., 1967).

Munurut Afridona (2005), penggunaan ekstrak tauge dalam pembuatan nata lebih ramah lingkungan dibanding urea karena berasal dari bahan organik, tidak menimbulkan residu berbahaya, mudah dibuat/diperoleh, dan telah terbukti menghasilan nata de coco yang berkualitas. Dalam pembuatan nata selain gula dan Acetobacter xyinum penambahan ekstrak tauge juga berfungsi untuk meningkatkan ketebalan nata. Jumlah starter dan lama fermentasi yang dilakukan dalam pembuatan nata dapat berpengaruh terhadap kualitas akhir produk (Awwaly et al., 2011). Untuk menghasilkan ketebalan nata yang maksimal, dapat ditambahkan starter Acetobacter xulinum 10 - 20\% dalam pembuatan nata (Alaban 1962 dalam Awwaly et al., 2011).

\section{METODE PENELITIAN}

Penelitian ini dilakukan pada bulam Mei - Oktober 2018 di Laboratorium Mikrobiologi dan Laboratorium Analisis Hasil Pertanian Program Studi Teknologi Hasil Pertanian, Fakultas Pertanian, Universitas Syiah Kuala, Banda Aceh dan politeknik lhokseumawe

\section{Bahan dan Alat}

Bahan yang digunakan yaitu air cucian beras, air kelapa, tauge, gula, cuka, Acetobacter xylinum, kertas koran, wadah plastik, kain saring, panci dan kertas saring. Bahan analisis yang digunakan yaitu $\mathrm{H}_{2} \mathrm{SO}_{4}, \mathrm{NaOH}$, heksan, aquades dan kertas saring.

Alat yang digunakan pada penelitian yaitu botol kaca, gelas ukur, erlenmeyer, timbangan analitik, kompor, pengaduk, blender, $\mathrm{pH}$ meter, pisau, kertas tisu, karet pengikat, jangka sorong, dan oven. Alat analaisis yang digunakan yaitu desikator, hot plate dan kertas saring.

\section{Rancangan Penelitian}

Metode yang digunakan pada penelitian ini adalah Rancangan Acak Lengkap (RAL) factorial yang terdiri dari 2 faktor. Faktor pertama yaitu jenis bahan baku (B) yang terdiri dari 2 taraf yaitu B1= air cucian beras dan B2= air kelapa. Faktor kedua yaitu konsentrasi ekstrak tauge yang terdiri dari 5 taraf yaitu $1=0 \%, \mathrm{~K} 2=0,25 \%, \mathrm{~K} 3=0,5 \%, \mathrm{~K} 4=0,75 \%$ dan $\mathrm{K} 5=1 \%$.

\footnotetext{
Variasi Penggunaan Jenis Bahan Baku (Air Cucian Beras dan Air Kelapa) Dengan Penambahan Ekstrak Tauge Terhadap Rendemen dan Mutu Nata (Nurul Izzati, Irfan, Syarifah Rohaya) 
Kombinasi perlakuan dalam penelitian ini adalah $2 \times 5=10$ (sepuluh) kombinasi perlakuan. Setiap perlakuan menggunakan 2 (dua) kali ulangan, sehingga diperoleh 20 satuan percobaan.

\section{Analisis Data}

Analisis data secara statistik menggunakan tabel ANOVA (Analysis of Variance). Perlakuan yang berpengaruh nyata dilakukan uji lanjut Duncan Multiple Testi (DMRT).

\section{Pembuatan Ekstrak Tauge}

Tauge ditimbang sebanyak $250 \mathrm{~g}$, dimasukkan ke dalam blender dan ditambahkan air sebanyak $250 \mathrm{ml}$. selanjutnya tauge diblender sampai halus, kemudian disaring dan diambil ekstrak tauge yang akan digunakan dalam pembuatan nata.

\section{Pembuatan Nata de Rice dan Nata de Coco}

Air cucian beras dan air kelapa disaring, diambil 1 liter, dimasukan ke dalam panci, kemudian dimasukkan gula $200 \mathrm{~g}$, onsentrasi ekstrak tauge $\mathrm{K} 1=0 \%, \mathrm{~K} 2=0,25 \%, \mathrm{~K} 3=0,5 \%$, $\mathrm{K} 4=0,75 \%$ dan $\mathrm{K} 5=1 \%$. Selanjutnya dimasak sampai suhu $100^{\circ} \mathrm{C}$ selama 15 menit. Media dituangkan ke dalam wadah yang sudah steril. Kemudian dimasukkan starter Acetobacter xylinum $200 \mathrm{ml}$. selanjutnya ditutup dengan kertas koran dan diikat dengan karet, kemudian difermentasi pada suhu kamar selama 14 hari.

\section{Analisis Rendemen (AOAC, 2007)}

Perhitungan rendemen berdasarkan perbandingan nata dengan berat bahan dan dinyatakan dalam bentuk persentase. Persentase rendemen nata dihitung dengan persamaan sebagai berikut :

$$
\text { Rendemen : } \frac{\text { Berat nata }(\mathrm{g})}{\text { Volume bahan }(\mathrm{ml})} \times 100 \%
$$

Analisis Kadar Air (AOAC, 2007)

Cawan porselin dimasukkan ke dalam oven dengan suhu $105^{\circ} \mathrm{C}$ selama 1 jam. Kemudian dimasukkan ke dalam desikator. Nata ditimbang 5 g dimasukkan ke dalam cawan porselin. Kemudian dikeringkan dalam oven dengan suhu $105^{\circ} \mathrm{C}$ selama 5 jam. Selanjutnya cawan tersebut dimasukkan ke dalam desikator dan ditimbang kembali. Persentase kadar air (berat basah) dapat dihitung sebagai berikut :

$$
\text { Kadar Air } \%=\frac{\mathrm{A}-\mathrm{B}}{\mathrm{A}} \times 100 \%
$$

Keterangan : A : Berat sampel sebelum dikeringkan.

B : Berat sampel setelah dieringkan.

\section{Analisis Serat Kasar (AOAC, 2007)}

Nata ditimbang $1 \mathrm{~g}$ dimasukkan ke dalam erlenmeyer, lalu ditimbang $\mathrm{H}_{2} \mathrm{SO}_{4} \quad 1,25 \%$

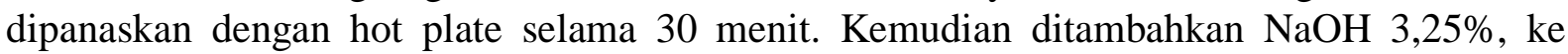
dalam erlenmeyer dan dipanaskan, kemudian disaring menggunakan kertas saring, selanjutnya dibilas menggunakan $\mathrm{H}_{2} \mathrm{SO}_{4}$ dan aquades lalu dikeringkan dalam oven. Kemudian dimasukkan ke dalam desikator dan ditimbang:

$$
\text { Serat Kasar }=\frac{(\mathrm{C}-\mathrm{B})-(\mathrm{E}-\mathrm{D})}{\mathrm{A}} \times 100 \%
$$

\footnotetext{
Variasi Penggunaan Jenis Bahan Baku (Air Cucian Beras dan Air Kelapa) Dengan Penambahan Ekstrak Tauge Terhadap Rendemen dan Mutu Nata (Nurul Izzati, Irfan, Syarifah Rohaya) 
Keterangan: A : Bobot contoh (g)

D : Bobot cawan kosong $(\mathrm{g})$

$\mathrm{B}$ : Bobot kertas saring kosong $(\mathrm{g})$

E : Bobot cawan + abu $(\mathrm{g})$

Analisis Ketebalan (Amiarsi, 2015)

Nata diukur menggunakan jangka sorong dan dinilai ketebalan yang didapat adalah rata - rata dari masing - masing nata yang terbentuk.

\section{Analisis Tekstur (Penetrometer, 2015)}

Kekenyalan tekstur nata diukur dengan menggunakan penetrometer. Pengukuran dilakukkan dengan penusukan pada lima tempat. Satuang pengukuran dinyatakan dalam $\mathrm{g} / \mathrm{cm}^{2}$ dari berat nata.

\section{HASIL DAN PEMBAHASAN}

\section{Rendemen}

Hasil analisis rendemen menunjukan bahwa nata memiliki nilai rendemen $2.01 \%$ $8.23 \%$ dengan rata - rata $5.80 \%$. Analisis ragam menunjukkan bahwa jenis bahan baku (B) dan konsentrasi ekstrak tauge $(\mathrm{K})$ berpengaruh sangat nyata $(\mathrm{P} \leq 0,01)$ terhadap rendemen nata yang dihasilkan, sedangkan interaksi kedua perlakuan (BK) tidak berpengaruh nyata terhadap rendemen nata. Pengaruh jenis bahan baku rendemen nata dapat dilihat pada Gambar 1, sedangkan pengaruh konsentrasi ekstrak tauge terhadap nilai rendemen nata dapat dilihat pada Gambar 2.

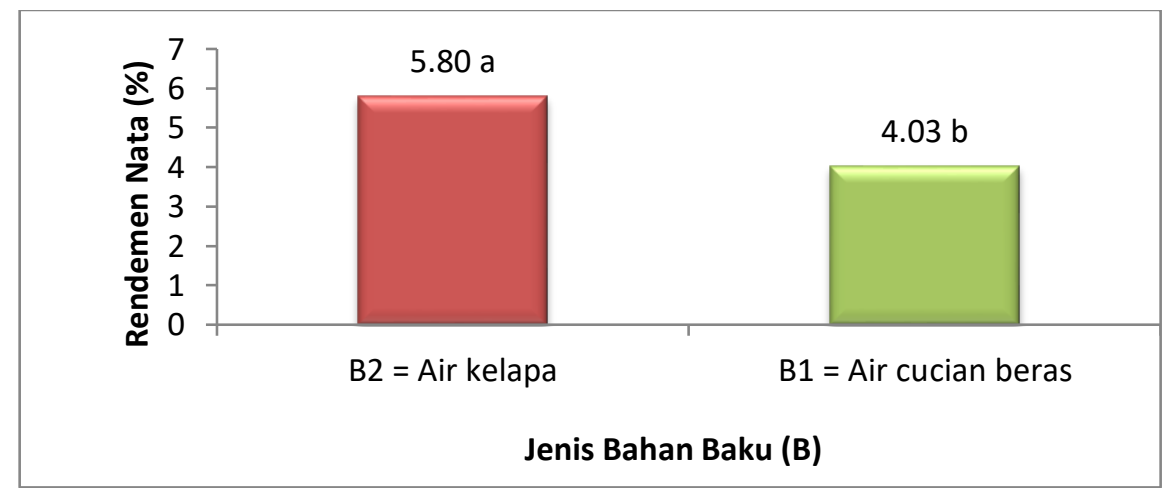

Gambar 1. Pengaruh perlakuan jenis bahan baku air cucian beras dan air kelapa terhadap rendemen nata pada uji lanjut $\mathrm{DMRT}_{0,01} ; 1.30$ (nilai yang diikuti oleh huruf yang sama tidak menunjukkan perbedaan yang nyata, $\mathrm{KK}=0 \%)$.

Uji DMRT $_{0,01}$ menunjukkan bahwa penggunaan jenis bahan baku air kelapa mempunyai nilai rendemen lebih tinggi $5.80 \%$ yang berbeda dengan jenis bahan baku air cucian beras $4.03 \%$. Menurut Pambayun (2002), air kelapa sangat bagus digunakan dalam pembuatan nata karena mengandung nutrisi yang baik bagi aktivitas Acetobacter xylinum. Kandungan utama yang terdapat pada air kelapa adalah karbohidrat, glukosa, fruktosa dan sukrosa (Gustian et al., 2006). Selain itu air kelapa juga mengandung natrium (Na), fosfor (P), magnesium $(\mathrm{Mg})$, kalsium $(\mathrm{Ca})$ dan kalium $(\mathrm{K})$, yang merupakan unsure mineral yang sangat diperlukan oleh Acetobacter xylinum. Kandungan nutrisi yang terdapat pada air kelapa lebih lengkap dari pada kandungan nutrisi pada air cucian beras, sehingga air kelapa memiliki nilai rendemen lebih tinggi dari air cucian beras.

Variasi Penggunaan Jenis Bahan Baku (Air Cucian Beras dan Air Kelapa) Dengan Penambahan Ekstrak Tauge Terhadap Rendemen dan Mutu Nata (Nurul Izzati, Irfan, Syarifah Rohaya) 


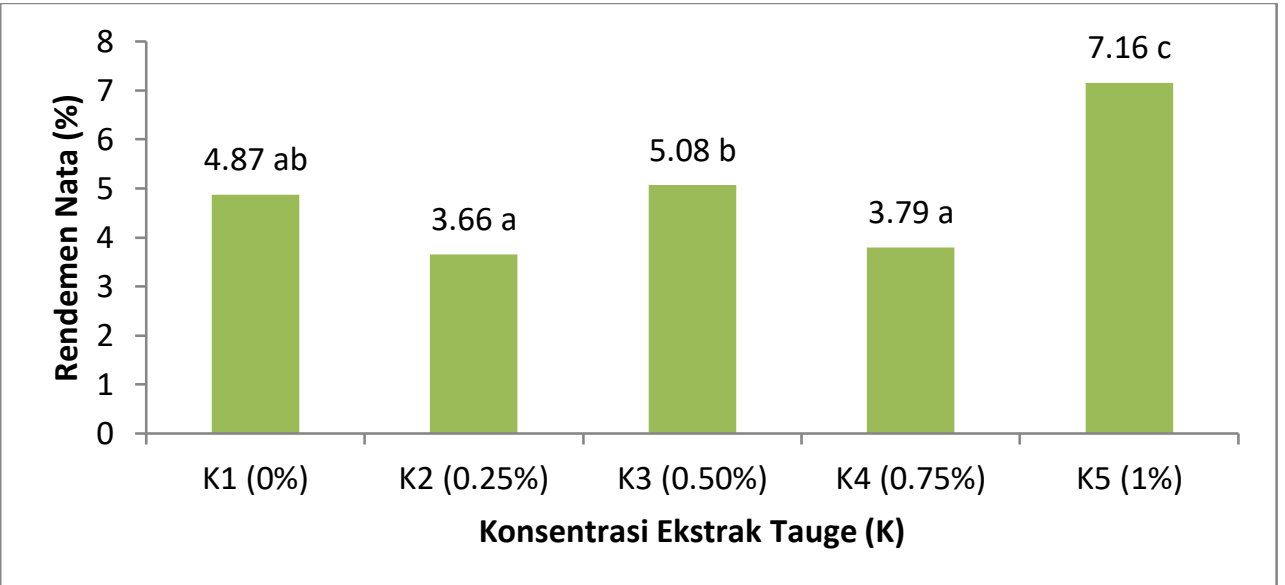

Gambar 2. Pengaruh konsentrasi ekstrak tauge terhadap rendemen nata pada uji lanjut $\mathrm{DMRT}_{0,01} ; 2.06 ; 2.15$; $2.20 ; 2.24$ (nilai yang diikuti oleh huruf yang sama tidak menunjukkan perbedaan yang nyata, $\mathrm{KK}=0 \%)$.

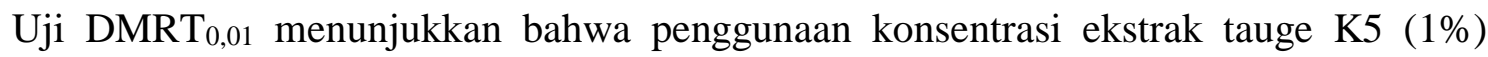
mempunyai nilai rendemen tertinggi yaitu $7.16 \%$, yang berbeda dengan penggunaan konsentrasi ekstrak tauge K2 (0.25\%) yaitu 3.66\%. Menurut Mody (2007), semakin banyak sumber nitrogen yang ditambahkan dalam pembuatan nata maka rendemen nata akan semakin meningat. Menurut Putriana dan Aminah (2013), ekstrak tauge kaya akan nutrisi baik dalam bentuk makro-nutrien, meso-nutrien, meso-nutrien maupun mikro-nutrien, yang berguna untuk menyusun protoplasma Acetobacter xylinum.

\section{Kadar Air}

Kadar air merupakan jumlah air dalam suatu bahan yang memberikan pengaruh terhadap daya simpan suatu produk pangan. Kadar air nata de rice dan nata de coco berkisar dari $69.11 \%$ - 81.49\% dengan rata - rata $75.61 \%$. Analisis ragam menunjukkan bahwa perlakuan jenis bahan baku (B) dengan penambahan konsentrasi ekstrak tauge (K), serta interaksinya $(\mathrm{BK})$ berpengaruh sangat nyata $(\mathrm{P} \leq 0,01)$ terhadap kadar air nata. Pengaruh interaksi perlakuan (BK) terhadap nilai kadar air nata dapat dilihat pada Gambar 3.

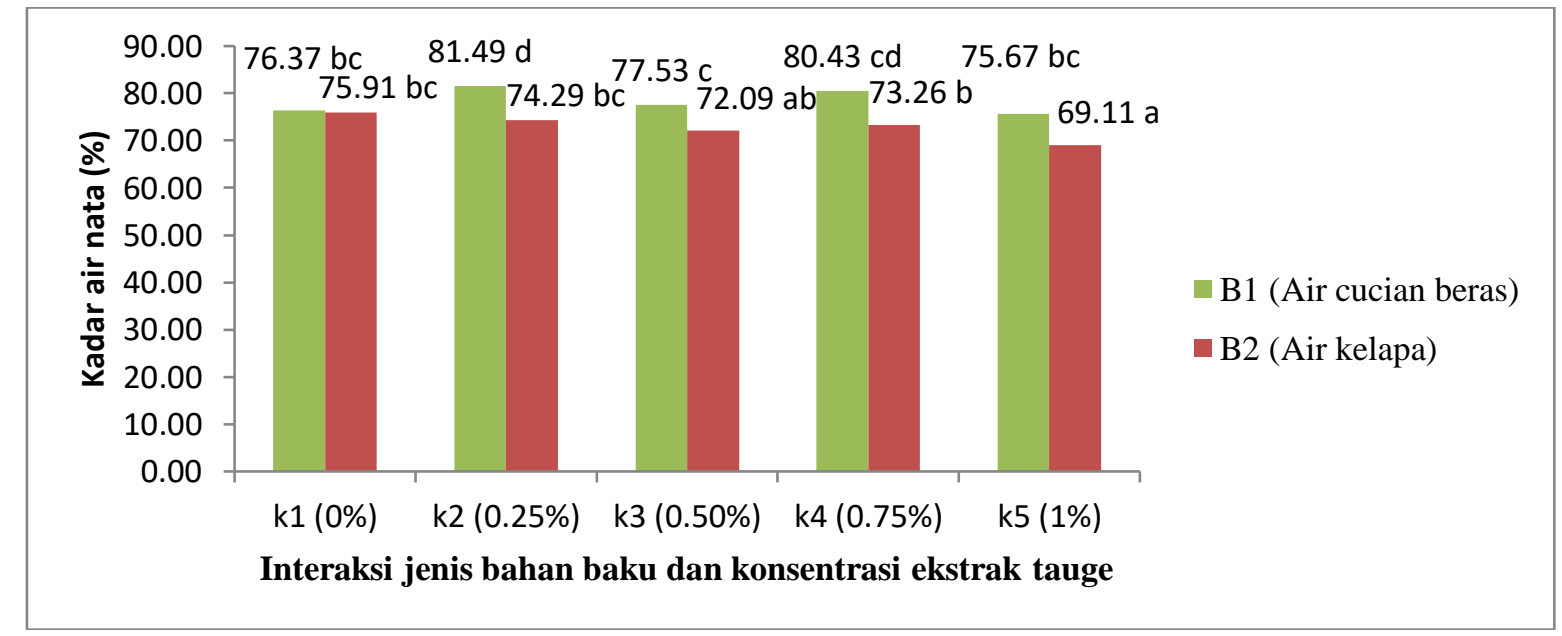

Gambar 3. Pengaruh interaksi perlakuan jenis bahan baku dan konsentrasi ekstrak tauge terhadap kadar air nata pada uji lanjut DMRT $_{0,01} ; 3.12 ; 3.25 ; 3.33 ; 3.39 ; 3.43 ; 3.46 ; 3.48 ; 3.50 ; 3.52$ (nilai yang diikuti oleh huruf yang sama tidak menunjukan perbedaan yang nyata, $\mathrm{KK}=11.3 \%$ ).

\footnotetext{
Variasi Penggunaan Jenis Bahan Baku (Air Cucian Beras dan Air Kelapa) Dengan Penambahan Ekstrak Tauge Terhadap Rendemen dan Mutu Nata (Nurul Izzati, Irfan, Syarifah Rohaya)

Jurnal Ilmiah Mahasiswa Pertanian, Vol. 4, No. 2, Mei 2019: 300-307
} 
Uji lanjut DMRT $_{0,01}$ menunjukkan bahwa kadar air nata B2K5 (Gambar 3) pada perlakuan jenis bahan baku air kelapa dengan penambahan konsentrasi ekstrak tauge (1\%), memiliki nilai kadar air paling rendah $(69.11 \%)$ dan umumnya berbeda dengan interaksi lainnya. Secara umum, semakin tinggi konsentrasi ekstrak tauge semakin rendah kadar air nata de coco yang dihasilkan. rendahnya kandungan kadar air pada nata bisa jadi karena selulosa yang terbentu sangat tinggi (Alviani, 2016). Kandungan kadar air yang terdapat pada nata dapat mempengaruhi tekstur nata yang dihasilkan. semakin tinggi kadar air yang terdapat pada nata maka tekstur nata semakin tidak mudah putus (alot). Hal ini disebabkan oleh adanya kandungan air yang tinggi menghasilkan serat (selulosa) yang lebih rendah, sehingga jaringan selulosa lebih longgar dan air mudah masuk yang akan menghasilkan nata dengan terkstur tidak mudah putus (Hastuti et al.,2017).

\section{Serat Kasar}

Jenis serat yang terdapat pada nata nata de rice dan nata de coco adalah serat kasar. Pada hasil uji serat kasar nata memiliki nilai $4.57 \% \%$ - 9.38\% dengan rata - rata $6.09 \%$. Analisis ragam menunjukkan bahwa jenis bahan baku (B), konsentrasi ekstrak tauge (K) dan interaksi kedua perlakuan $(\mathrm{BK})$ berpengaruh tidak nyata $(\mathrm{P}>0,05)$ terhadap kadar serat kasar nata sehingga uji lanjut DMRT tidak dilanjutkan. Hal ini menunjukkan bahwa penggunaan jenis bahan baku dengan penambahan konsenatrasi ekstrak tauge yang berada dalam media fermentasi tercukupi dan proses inkubasi yang dilakukan benar - benar terjaga sehingga pertumbuhan bakteri selama inkubasi berjalan dengan baik. Tidak terjadi goncangan selama inkubasi, $\mathrm{pH}$ dan suhu ruangan yang sesuai juga mendukung aktivitas bakteri dalam menghasilkan serat tidak terganggu.

\section{Ketebalan}

Ketebalan merupakan hasil metabolisme bakteri Acetobacter xylinum yang dapat digunakan sebagai parameter untuk mengetahui pertumbuhan dan kemampuan bakteri tersebut dalam mengkonversi nutrisi menjadi selulosa. Pada uji $\mathrm{DMRT}_{0,05}$ menunjukkan bahwa interaksi kedua perlakuan $(\mathrm{BK})$ berpengaruh nyata $(\mathrm{P}<0.05)$ terhadap ketebalan nata. Rata - rata ketebalan nata berkisar dari $0.02 \mathrm{~cm}-0.56 \mathrm{~cm}$. Interaksi penggunaan jenis bahan baku (B) dengan penambahan konsentrasi ekstrak tauge (K) dapat dilihat pada Gambar 4.

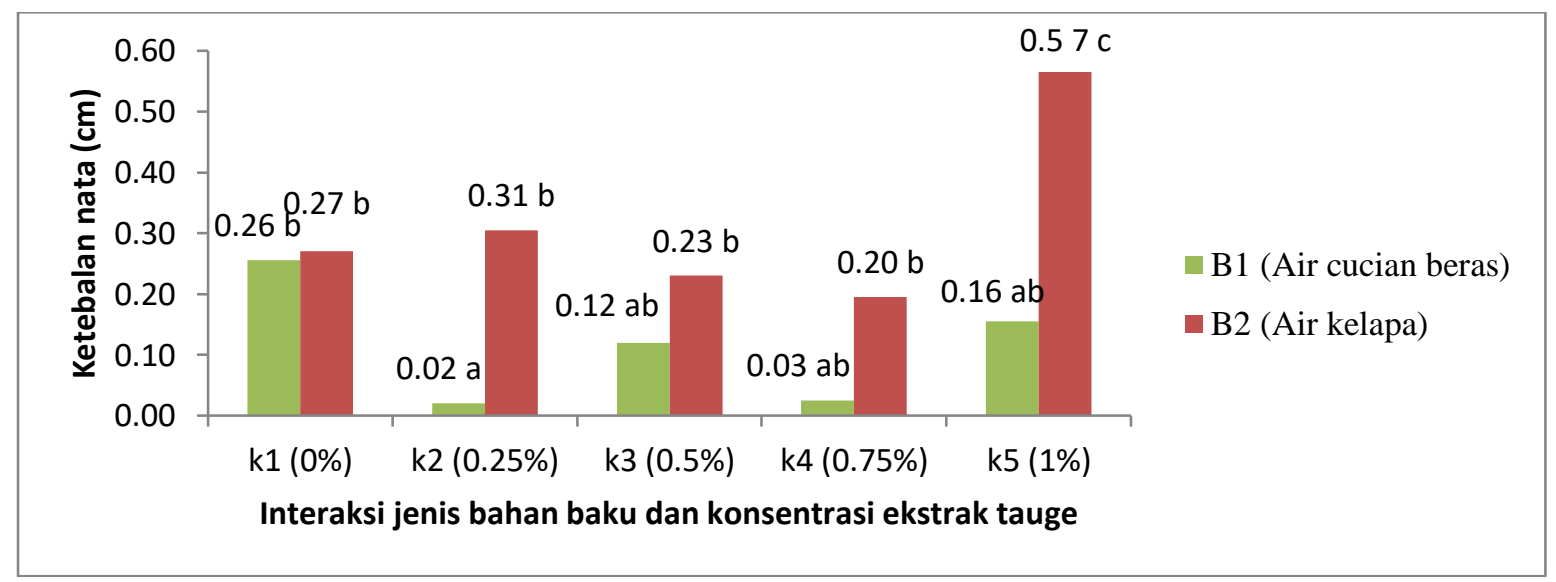

Gambar 4. Pengaruh perlakuan jenis bahan baku dengan penambahan konsentrasi ekstrak tauge terhadap ketebalan nata pada uji lanjut DMRT $0.05 ; 0.16 ; 0.17 ; 0.17 ; 0.18 ; 0.18 ; 0.18 ; 0.18 ; 0.18 ; 0.18$ (nilai yang diikuti oleh huruf yang sama tidak menunjukkan perbedaan yang nyata, $\mathrm{KK}=16.2 \%$ ).

\footnotetext{
Variasi Penggunaan Jenis Bahan Baku (Air Cucian Beras dan Air Kelapa) Dengan Penambahan Ekstrak Tauge Terhadap Rendemen dan Mutu Nata (Nurul Izzati, Irfan, Syarifah Rohaya)

Jurnal Ilmiah Mahasiswa Pertanian, Vol. 4, No. 2, Mei 2019: 300-307
} 


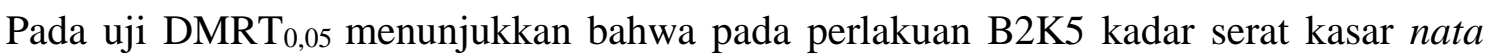
penggunaan jenis bahan baku air kelapa dengan penambahan konsentrasi ekstrak tauge $(1 \%)$ memiliki ketebalan nata paling tinggi $(0.57 \mathrm{~cm})$. Menurut Fifendy et al.,(2011) dengan adanya penambahan konsentrasi ekstrak tauge sebagai sumber nitrogen dalam pembuatan nata dapat menghasilkan ketebalan nata yang lebih baik dibandingkan tanpa penambahan sumber nitrogen dan urea, baik dari segi ketebalan, serat maupun kekenyalan. Jika sumber karbon dan sumber nitrogen yang digunakan dalam pembuatan nata terlalu sedikit dapat menyebabkan terjadinya persaingan antara sel bakteri dalam memenuhi kebutuhan nutrisi sehingga banyak bakteri yang mati. Jumlah bakteri yang sedikit dapat mempengaruhi hasil metabolisme dalam menghasilkan selulsa. Hal ini sesuai dengan penelitian Hastuti et $a l .,(2017)$ semakin tinggi konsentrasi ekstrak tauge yang digunakan dalam pembuatan nata, maka semakin tebal nata yang dihasilkan.

\section{Tekstur}

Dari hasil analisis tekstur yang telah dilakukan, dapat dilihat bahwa perlakuan jenis bahan baku dengan penambahan konsentrasi ekstrak tauge memiliki hasil yang berbeda. Pada perlakuan penambahan konsentrasi ekstrak tauge B2K5 (1\%) pada jenis bahan baku air kelapa memiliki nilai tekstur paling tinggi $\left(289.5 \mathrm{~g} / \mathrm{cm}^{2}\right)$, sedangan pada perlakuan B1K1 penggunaan jenis bahan baku air cucian beras dengan penambahan konsentrasi ekstrak tauge $(0 \%)$ memiliki nilai tekstur paling rendah $(67 \mathrm{~g} / \mathrm{cm} 2)$.

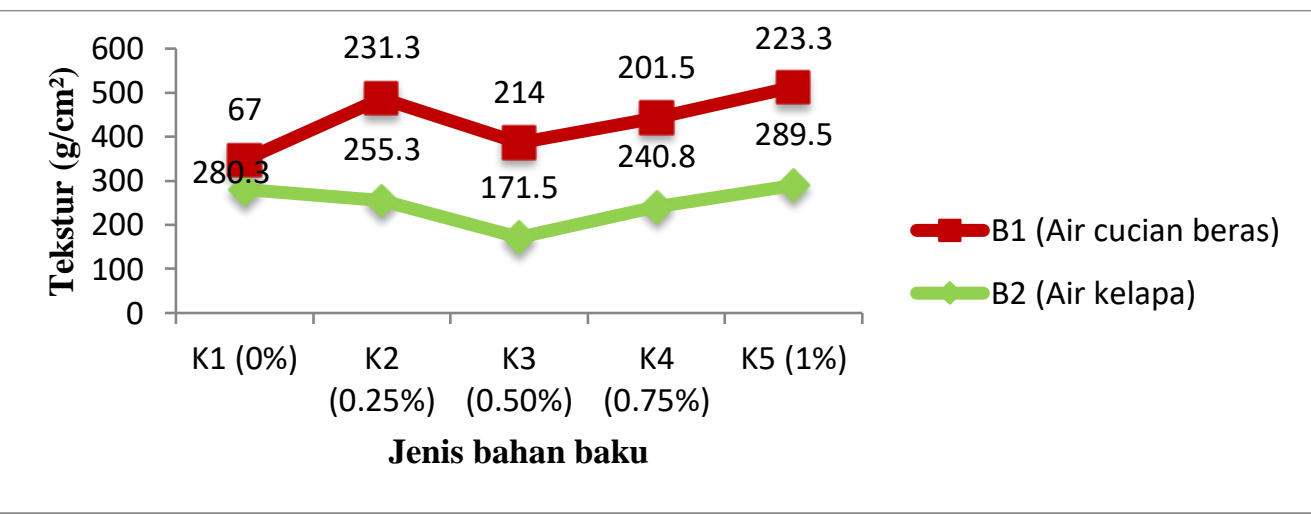

Gambar 5. Pengaruh jenis bahan baku air cucian beras dan air kelapa dengan penambahan konsentrasi ekstrak tauge terhadap tekstur nata (nilai yang diikuti oleh huruf yang sama tidak menunjukkan perbedaan yang nyata).

Menurut Safitri et al., (2017) semakin tinggi konsentrasi ekstrak tauge yang digunakan dalam pembuatan nata, maka kandungan serat yang terdapat pada nata juga meningkat. Hal tersebut dapat mempengaruhi terhadap serat kasar yang akan berbanding lurus dengan kekenyalan dan tekstur. Penggunaan sumber nitrogen yang tinggi akan menghasilkan tekstur nata yang kenyal. Menurut Safitri et al., (2017), mengatakan bahwa tekstur suatu produk nata dapat dipengaruhi oleh banyak sedikitnya serat nata. Semakin banyak kandungan serat di dalam nata maka semakin kenyal tekstur nata tersebut.

\section{KESIMPULAN}

Secara umum pada penggunaan jenis bahan baku air kelapa dengan penambahan konsentrasi ekstrak tauge (1\%) dihasilkan rendemen nata terbaik yaitu $8.23 \%$, dengan ketebalan $0.57 \mathrm{~cm}$ dan tekstur $289.5 \mathrm{~g} / \mathrm{cm}^{2}$. Rendemen nata yang dihasilkan dari air cucian beras $(4.02 \%)$ secara umum lebih rendah dari rendemen nata air kelapa $(4.02 \%-5.79 \%)$.

Variasi Penggunaan Jenis Bahan Baku (Air Cucian Beras dan Air Kelapa) Dengan Penambahan Ekstrak Tauge Terhadap Rendemen dan Mutu Nata (Nurul Izzati, Irfan, Syarifah Rohaya)

Jurnal Ilmiah Mahasiswa Pertanian, Vol. 4, No. 2, Mei 2019: 300-307 


\section{DAFTAR PUSTAKA}

Afridona, W. 2006. Pemberian Nata de Coco Dengan Sumber Nitrogen Organik Yang Betbeda. Skripsi Jurusan Biologi FMIPA. Universitas Negeri Padang.

Alviani, D, K. 2016. Pengaruh Konsentrasi Gula Kelapa dan Starter Acetobacter xylinum Terhadap Kualitas Fisik dan Kimiawi Nata de Rice. Skripsi. Universitas Islam Negeri (UIN) Maulana Malik Ibrahim Malang, Malang.

(AOAC) Association of Official Analitycal Chemist. 2007. Official Methods of Analysis of Official Analytical of Chemist. Airlington: The Assosiatin of Official Analytical Chamists. $18^{\text {th }}$ edn. Washington Dc.

Fifendy, M. Putri, D. H, dan Maria, S, S. 2011. Pengaruh Penggunaan Tauge Sebagai Sumber Nitrogen Terhadap Mutu Nata de Kakao. Jurnal Sainteks, 3(2), 165-170.

Fitriah, L. 2007. Pemanfaatan Air Cucian Beras Sebagai Bahan Pembuatan Nata (Seminar Kimia) Fakultas FMIPA Ilmu keguruan dan Ilmu Pendidikan Mataram.

Gustian, I. Susanto, D. T, dan Adfa, M. 2006. Efek Perendaman Larutan Alkali Terhadap Prilaku Film Kertas Dari Nata de Coco Yang Dimodifikasi. Jurnal Gardien, Vol. 2, No.1, Januari 2016 : 126-129.

Hastuti, M. Andriyani, M. Wiedyastanto, A. Gisyamadia, dan S. D, Margono. 2017. Pemanfaatan Estrak Kecambah Kacang Hijau Sebagai Sumber Nitrogen Alternatif Dalam Pembuatan Nata de Lerry. Program Studi Teknik Kimia, Universitas Sebelas Maret.

Hidayarullah, R. 2012. Pemanfaatan Limbah Air Cucian Beras Sebagai Substrat Pembuatan Nata de Leri Dengan Penambahan Kadar Gula Pasir dan Starter Berbeda. Skripsi. Program Studi Biologi UIN Sunan Kalijaga, Yogyakarta.

Lapuz, M. M, E. G. Gullardo dan M. A. Palo. 1967. The Nata Organism-Cultural Requirement Characteristic and Identity. Philipine J. of Sci. 96 (2) : 91-97 p.

Naufalin, R, dan Wibowo, C. 2003. Pengaruh Penambahan Sukrosa dan Ekstrak Kecambah Pada Kualitas Nata de Cassava. Jurnal Pembangunan Pedesaan, Vol. 3, No. 3, 49-56.

Ramadhani, A. 2002. Pengaruh Kombinasi Sukrosa dan Amonium Sulfat Terhadap Mutu Nata de Tomato. Skripsi. Jurusan Biologi FMIPA, Universitas Negeri Padang.

Safitri, P. M, Caronge, W. M. dan Kadirman. 2017. Pengaruh Pemberian Sumber Nitrogen dan Bibit Bakteri Acetobacter xylinum Terhadap Kualitas Hasil Nata de Tala. Jurnal Pendidikan Teknologi Pertanian, Vol. 3 (2017) :95-106.

Sihmawati, R, R. Oktoviani, D. dan Wardah. 2014. Aspek Mutu Produk Nata de Coco Dengan Penambahan Sari Buah Mangga. Jurnal Teknik Industri HEURISTIC, Vol. 11, No. 2, Oktober 2012.

Suratmiyati, Musofa, A. dan Kurniawati, L. 2009. Pemanfaatan Limbah Leri Beras (Hitam, Merah, Putih) Untuk Pembuatan Nata de Leri Dengan Faktor Lama Fermentasi. Abstrak Fakultas Teknologi dan Industri Pangan. Universitas Slamet Riyadi Surakarta.

Patria, A. Muzaifa, M. dan Zurrahmah. 2013. Pengaruh Penambahan Gula dan Amonium Sulfat Terhadap Kualitas Nata de Soya. Jurnal Teknologi dan Industri Pertanian Indonesia, Vol. 5, No. 3, 2013.

Pambayun, R. 2002. Tenologi Pengolahan Nata de Coco. Yogyakarta, Kanisius.

Putriana, I. dan Aminah, S. 2013. Mutu Fisik Kadar Serat dan Sifat Organoleptik Nata de Cassava Berdasarkan Lama Fermentasi. Jurnal Pangan dan Gizi (4) : 29-38.

\footnotetext{
Variasi Penggunaan Jenis Bahan Baku (Air Cucian Beras dan Air Kelapa) Dengan Penambahan Ekstrak Tauge Terhadap Rendemen dan Mutu Nata (Nurul Izzati, Irfan, Syarifah Rohaya)

Jurnal Ilmiah Mahasiswa Pertanian, Vol. 4, No. 2, Mei 2019: 300-307
} 